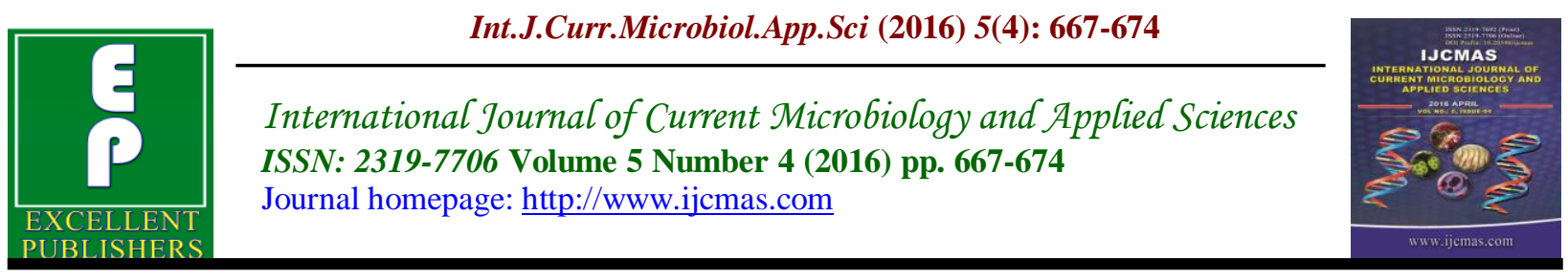

Original Research Article

http://dx.doi.org/10.20546/ijcmas.2016.504.076

\title{
Evaluation of CERES-Rice Model under Various Plant Densities and Age of Seedlings in Transplanted Rice of Southern Telangana Zone of Telangana State, India
}

\author{
G. Vijayalaxmi ${ }^{1 *}$, G. Sreenivas ${ }^{1}$ and P. Leela Rani $^{2}$ \\ ${ }^{1}$ Agriculture Research Iinstitute, PJTSAU, Rajendra Nagar, Hyderabad, India \\ ${ }^{2}$ AICRP on Weed Management, PJTSAU, Rajendra Nagar, Hyderabad, India \\ *Corresponding author
}

\section{A B S T R A C T}

Keywords

CERES Rice

Model

evaluation,

Plant densities,

Age of seedlings,

Transplanted rice.

\section{Article Info}

Accepted:

22 March 2016

Available Online:

10 April 2016
Field experiment was conducted during kharif, 2013 at college farm, Prof. Jayashankar Telangana State Agricultural University, Rajendranagar, Hyderabad. The soil of experimental field was sandy loam in texture, alkaline in reaction $(\mathrm{pH}$ 8.02), free from salts (EC $\left.0.39 \mathrm{dsm}^{-1}\right)$, low in organic carbon $(0.88 \%)$, available nitrogen $\left(210 \mathrm{~kg} \mathrm{ha}^{-1}\right)$, available phosphorus $\left(14.14 \mathrm{~kg} \mathrm{ha}^{-1}\right)$ and potassium $(249.76$ $\left.\mathrm{kg} \mathrm{ha}^{-1}\right)$. The investigation was carried out with three plant densities $(1,3$ and 5 seedlings hill-1) and four age of seedlings (15, 25, 35 and 45 days old seedlings). Model evaluation revealed that simulation of phenology at heading and physiological maturity was considered as excellent with NRMSE of 3\% and 3\%, with lesser RMSE values of 2.0 days and 3 days respectively. However, simulation of total biomass and grain yield was good with NRMSE of $14 \%$ and $12 \%$, having RMSE values of 1711 and $683 \mathrm{~kg} \mathrm{ha}^{-1}$ respectively. So model can be used as a research tool in the variable agro-environments of Telangana State to suggest suitable management practices to rice under low land transplanted conditions.

\section{Introduction}

Rice is the staple food for more than half of the world's population and plays a pivotal role in food security of many countries. More than $90 \%$ of the global production and consumption of rice is in Asia (IRRI, 1997). As for India, rice is not only a food commodity but also a source of foreign exchange earning about 11,000 cores annually. At the current rate of population growth $(1.5 \%)$, the rice requirement by the year 2025 would be about 120 million tons by 2025 as against 104.32 million tons to feed its one and a half billion plus population by then (RKMP, 2013).

Rice producers of Telangana State often encounter circumstances that result in delayed transplanting due to late release of water in the canals, tanks due to delayed onset of monsoon lead to transplanting of aged seedlings and more number of seedlings hill $^{-1}$ as a part of management 
practice under delayed transplanting. This ultimately resulted in lower yields. So maintenance of optimum plant densities (no. of seedlings hill-1) and age of seedlings are the two key management practices for rice production (Sarwa et al., 2011,).

At present, information required for the rice production improvement with suitable management practices is a need of hour. The generation of new data through agronomic research methods is insufficient and time consuming to meet these needs. So crop simulation models are considered as potentially useful tools in agricultural decision making (Rinaldi et al., 2007).

So there is need to generate data to validate the previously calibrated model under varied plant densities and age of seedlings of Southern Telangana zone by using short term field experiment to validate DSSAT v 4.5. Keeping these facts in view, the present investigation was carried out to validate the CERES Rice model with experimental data for further applications without resorting to vigorous experimentation.

\section{Materials and Methods}

The experiment was conducted during kharif, 2013 at Professor Jayashankar Telangana State Agricultural University, Rajendranagar, Hyderabad having an altitude of $542.3 \mathrm{~m}$ above mean sea level at $17^{\circ} 19^{\prime} \mathrm{N}$ latitude and $78^{\circ} 23^{\prime}$ 'E longitude. The soil of the experimental site was sandy loam in texture, alkaline in reaction, low in available nitrogen, available phosphorus and available potassium. The experiment was carried out with three plant densities viz., 1, 3 and 5 seedlings hill $^{-1}$ as factor one and four age of seedlings 15, 25, 35, 45 days old seedlings as factor two in RBD (factorial), replicated thrice. The data collected from the experiment was used to validate the CERES-
Rice model. Statistical indices like RMSE and Normalized RMSE were used for model evaluation.

\section{CERES Rice Model Description}

CERES-Rice model (Ritchie et al., 1986) was selected as a tool for simulating growth and yield of rice under different environment and management strategies. The CERES-Rice model simulates rice crop growth and development from either planting or transplanting to physiological maturity and is based on the physiological processes that describe the response of rice to local soil and weather conditions. Potential growth is mainly dependent upon photosynthetically active radiation (PAR), light interception and the light conversion efficiency, while actual growth is a constraint of crop management, soil and weather interactions.

\section{Input Requirements to run CERES-Rice Model}

The input data required to run the DSSAT models include daily weather data, i.e. maximum and minimum temperature, rainfall, and solar radiation; soil characterization data, genetic coefficients and crop management information, such as date of planting, age of seedlings, row and plant spacing, rates and dates and amount of fertilizer and irrigation applied. Input data files of CERES-Rice model are as per IBSNAT standard input/output formats and file structure described in DSSAT $\mathrm{v} 4.5$ (Hoogenboom et al., 2003).

\section{Simulation Studies}

After the weather, soil, genotype and crop management input files were created for a specified simulation experiment, the CERES -Rice model was run and output files were 
generated. These simulation results were compared with observed data.

\section{Model Validation}

To check the accuracy of model simulations it was validated with data recorded for three plant densities and four age of seedlings during the year 2013. The genetic coefficients of MTU-1010 needed to run the model were furnished in the Table 1 (Swarna, 2013). During all this process available data on heading, physiological maturity, grain yield and total crop biomass was compared with simulated values.

\section{Statistical Analysis}

Statistical based criteria provide a more objective method for evaluation of the performance of the models (Ducheyne, 2000). RMSE and NRMSE are common statistical tools to test the goodness of fit of simulation models (Wallach and Goffinet, 1989). The computed values of RMSE determine the degree of agreement between the simulated values with their respective observed values and a low RMSE value that approaches zero is desirable. The RMSE was calculated according to equation

RMSE (root mean square error) $=\left[\sum_{i=1}^{n}\left(p_{i}-o_{i}\right)^{2} / n\right]^{0.5}$

In addition to this overall performance of model was estimated using Normalized RMSE (RMSEn), which gives a measure (\%) of the relative difference of simulated verses observed data. The simulation is considered excellent with a normalized RMSE less than $10 \%$, good if the normalized RMSE is greater than 10 and less than $20 \%$, fair if the normalized RMSE is greater than $20 \%$ and less than $30 \%$, and poor if the normalized RMSE is greater than
30\% (Loague and Green, 1991). The RMSEn was calculated following Equation.

Normalized root mean square error = $\left[\frac{R M S E}{\bar{O}}\right] x 100$

The Coefficient of Residual Mass (CRM) was also used to measure the tendency of the model to overestimate or under estimate the measured values. The CRM is defined by

Coefficient of Residual Mass $(\mathrm{CRM})=$ $\frac{\sum_{i=1}^{n} O_{i}-\sum_{i=1}^{n} P_{i}}{\sum_{i=1}^{n} O_{i}}$

Where $\mathrm{O}_{\mathrm{i}}$ and $\mathrm{P}_{\mathrm{i}}$, are the observed and predicted values respectively for the $i^{\text {th }}$ data point of $n$ observations. A negative CRM indicates a tendency of the model towards over estimation (Xevi et al., 1996).

\section{Results and Discussion}

Model simulation efficiency was evaluated with the data obtained from three plant densities and four age of seedlings during the year 2013. During this process the collected data on phenology, biomass, grain yield and nitrogen uptake by grain were compared with the simulated values using statistical indices.

\section{Days to Heading}

Simulated values of days to heading was closer to the observed data, with RMSE value of 2.0 days, CRM value of 2.2 and NRMSE value of $3 \%$. This clearly idicates that, CERES-Rice model under estimated the days to heading to the extent of $2.2 \%$. However, under present study simulation of days to heading was considered excellent as the normalized RMSE (NRMSE) value was less than $10 \%$ (Table 2) 


\section{Days to Physiological Maturity}

A difference of 3 days was noticed between observed and simulated values to attain physiological maturity with RMSE, NRMSE and the CRM values of 3 days, 3 and $-2.5 \%$ respectively (Table 3 ), showed the tendency of model to overestimate the days to physiological maturity by $2.5 \%$. However, the simulation was considered as excellent with NRMSE value was being less than $10 \%$. Similar results obtained from validation of different rice models by Wikarmpapraharn and Kositsakulchai (2010) who observed the closer simulated values from ORYZA 2000 model than those obtained from CERES-Rice model.

Table.1 Genetic Coefficients of MTU1010 used for CERES-Rice Model

\begin{tabular}{|c|c|c|}
\hline S.No. & Description of coefficients & Value \\
\hline 1 & $\begin{array}{l}\mathbf{P}_{1} \text { : time period (expressed as growing degree days (GDD) in }{ }^{\circ} \mathrm{c} \text { above a base temperature of } 9^{\circ} \mathrm{C} \text { ) from } \\
\text { seedling emergence during which the rice plant is not responsive to changes in photoperiod. This } \\
\text { period is also referred as the basic vegetative phase of the plant. }\end{array}$ & 450 \\
\hline 2 & $\begin{aligned} \mathbf{P}_{2} \mathbf{0}: \text { Critical photoperiod or the longest day length (in hours) at } \\
\text { which the development occurs at a maximum rate. At values } \\
\text { higher than P20 developmental rate is slowed, hence there is } \\
\text { delay due to longer day lengths. }\end{aligned}$ & 12 \\
\hline 3 & $\begin{array}{l}\mathbf{P}_{2} \mathbf{R} \text { : Extent to which phasic development leading to panicle } \\
\text { initiation is delayed (expressed as }{ }^{0} \mathrm{C} \text { ) for each hour } \\
\text { increase in photoperiod above P20. }\end{array}$ & 160 \\
\hline 4 & $\begin{array}{l}\text { P5: Time period in GDD }\left({ }^{\circ} \mathrm{C}\right) \text { from beginning of grain filling }(3 \text { to } 4 \\
\text { days after flowering) to physiological maturity with a base } \\
\text { temperature of } 9^{\circ} \mathrm{c} \text {. }\end{array}$ & 350 \\
\hline 5 & $\begin{array}{l}\mathbf{G}_{1} \text { : Potential spikelet number co-efficient as estimated from the number of spikelets per g of main } \\
\text { culm dry weight (less leaf blades and sheaths plus spikes) at anthesis. A typical value is } 55 \text {. }\end{array}$ & 55 \\
\hline 6 & $\begin{array}{l}\text { G2: Single grain weight (g) under ideal growing conditions, i.e. non-limiting light, water, nutrients and } \\
\text { absence of pests and diseases. }\end{array}$ & 0.0250 \\
\hline 7 & $\begin{array}{l}\text { G3: Tillering co-efficients (scalor value) relative to IR64 cultivar under ideal conditions. A higher } \\
\text { tillering cultivar would have co-efficient greater than 1.0. }\end{array}$ & 1 \\
\hline 8 & $\begin{array}{l}\text { G4: Temperature tolerance co-efficient. Usually } 1.0 \text { for varieties grown in normal environments. G4 } \\
\text { for japonica type rice growing in a warmer environment would be } 1.0 \text { or greater. Likewise, the } \\
\text { G4 value for Indica type rice in very cool environments or season would be less than } 1.0\end{array}$ & 1 \\
\hline
\end{tabular}

Figure.1 Observed and Simulated Biomass (kg ha-1) at Heading of Rice using CERES-Rice Model at Different Plant Densities and Age of Seedlings

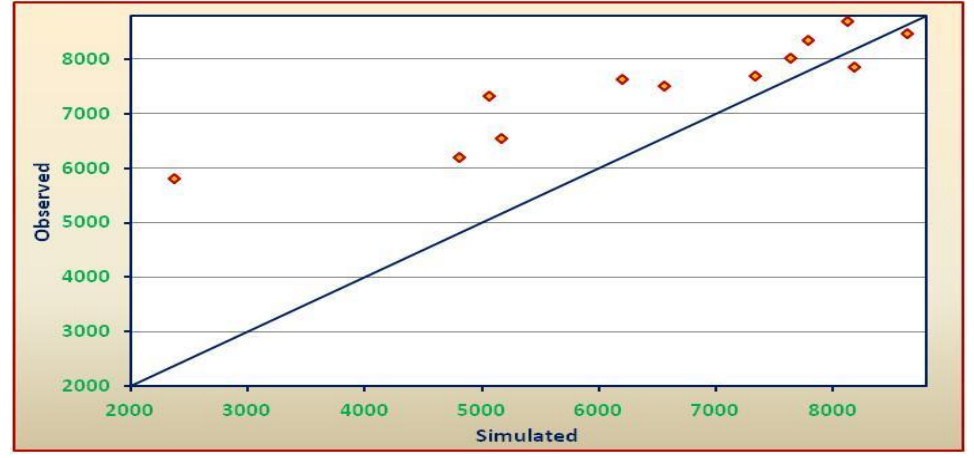


Table.2 Comparison of Simulated and Observed Days to Attain Heading of Rice under Varied Plant Densities and Age of Seedlings

\begin{tabular}{|c|c|c|c|}
\hline Treatments & Simulated & Observed & Difference \\
\hline $\mathrm{D}_{1} \mathrm{~S}_{1}$ & 72 & 75 & -3 \\
\hline $\mathrm{D}_{1} \mathrm{~S}_{2}$ & 72 & 75 & -3 \\
\hline $\mathrm{D}_{1} \mathrm{~S}_{3}$ & 72 & 73 & -1 \\
\hline $\mathrm{D}_{2} \mathrm{~S}_{1}$ & 66 & 69 & -3 \\
\hline $\mathrm{D}_{2} \mathrm{~S}_{2}$ & 66 & 69 & -3 \\
\hline $\mathrm{D}_{2} \mathrm{~S}_{3}$ & 66 & 68 & -2 \\
\hline $\mathrm{D}_{3} \mathrm{~S}_{1}$ & 61 & 62 & 0 \\
\hline $\mathrm{D}_{3} \mathrm{~S}_{2}$ & 61 & 61 & 0 \\
\hline $\mathrm{D}_{3} \mathrm{~S}_{3}$ & 61 & 60 & -1 \\
\hline $\mathrm{D}_{4} \mathrm{~S}_{1}$ & 55 & 56 & -1 \\
\hline $\mathrm{D}_{4} \mathrm{~S}_{2}$ & 55 & 56 & -1 \\
\hline $\mathrm{D}_{4} \mathrm{~S}_{3}$ & 55 & 55 & 0 \\
\hline $\mathrm{RMSE}$ & \multicolumn{4}{|c|}{2} \\
\hline $\mathrm{NRMSE}$ & \multicolumn{4}{|c}{} \\
\hline $\mathrm{CRM}$ & 3 & \\
\hline
\end{tabular}

Figure.2 Observed and Simulated Biomass (kg ha-1) at Physiological Maturity of Rice using CERES-Rice Model at Different Plant Densities and Age of Seedlings

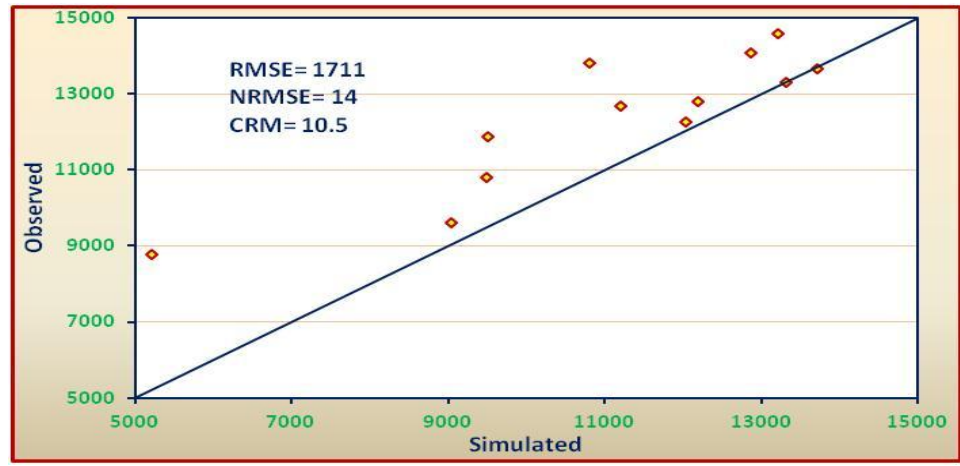

Figure.3 Observed and Simulated Grain Yield (kg ha-1) of Rice using CERES- Rice Model at Different Plant Densities and Age of Seedlings

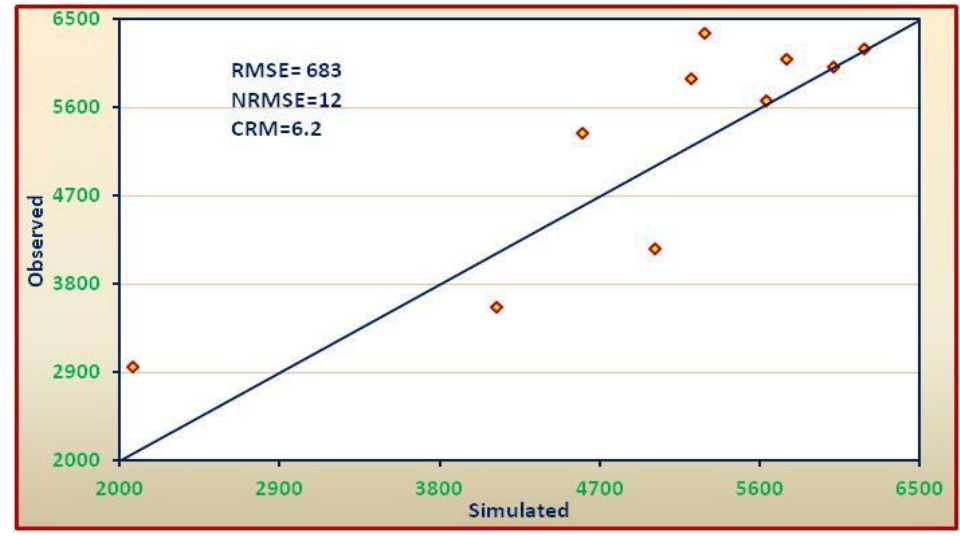


Table.3 Comparison of Simulated and Observed Days to Attain Physiological Maturity of Rice under Varied Plant Densities and Age of Seedlings

\begin{tabular}{|c|c|c|c|}
\hline Treatments & Simulated & Observed & Difference \\
\hline $\mathrm{D}_{1} \mathrm{~S}_{1}$ & 108 & 107 & 1 \\
\hline $\mathrm{D}_{1} \mathrm{~S}_{2}$ & 108 & 106 & 2 \\
\hline $\mathrm{D}_{1} \mathrm{~S}_{3}$ & 108 & 105 & 3 \\
\hline $\mathrm{D}_{2} \mathrm{~S}_{1}$ & 105 & 99 & 6 \\
\hline $\mathrm{D}_{2} \mathrm{~S}_{2}$ & 101 & 98 & 3 \\
\hline $\mathrm{D}_{2} \mathrm{~S}_{3}$ & 101 & 97 & 4 \\
\hline $\mathrm{D}_{3} \mathrm{~S}_{1}$ & 97 & 93 & 4 \\
\hline $\mathrm{D}_{3} \mathrm{~S}_{2}$ & 93 & 92 & 1 \\
\hline $\mathrm{D}_{3} \mathrm{~S}_{3}$ & 93 & 91 & 2 \\
\hline $\mathrm{D}_{4} \mathrm{~S}_{1}$ & 87 & 86 & 1 \\
\hline $\mathrm{D}_{4} \mathrm{~S}_{2}$ & 86 & 85 & 1 \\
\hline $\mathrm{D}_{4} \mathrm{~S}_{3}$ & 86 & 85 & 1 \\
\hline $\mathrm{RMSE}$ & \multicolumn{3}{|c|}{3} \\
\hline $\mathrm{NRMSE}$ & \multicolumn{3}{|c}{} \\
\hline $\mathrm{CRM}$ & \multicolumn{3}{|c}{} \\
\hline
\end{tabular}

Figure.4 Observed and Simulated N uptake by Grain (kg ha-1) of Rice using CERES- Rice Model at Different Plant Densities and Age of Seedlings

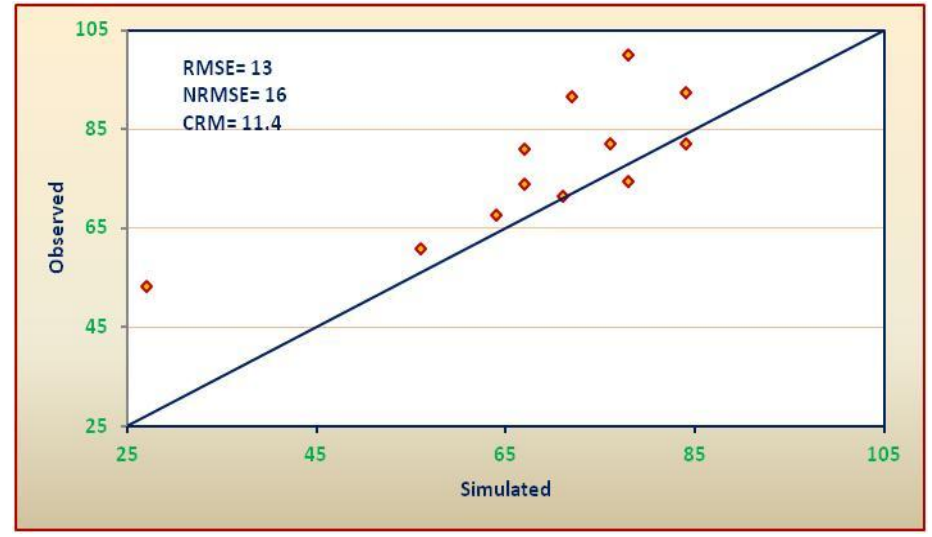

Biomass at Heading Physiological Maturity

The simulation of biomass at heading was considered good with NRMSE value of $19 \%$ due to underestimation of biomass by $13.6 \%$ with CRM value of 13.6 (Figure $1 \& 2$ ). The higher value of RMSE reflected that the model predicted above-ground biomass was quite good.

Biomass simulation at physiological maturity stage with observed data was similar to the heading stage with RMSE, NRMSE and CRM value of $1711 \mathrm{~kg} \mathrm{ha}^{-1}$, $14 \%$ and 10.5 respectively, which showed the model tendency to under predict the total biomass by $10.5 \%$. The higher RMSE and NRMSE values indicated the good simulation of biomass at physiological maturity.

\section{Grain Yield}

Simulated grain yield was closely related to the observed data with RMSE, NRMSE and 
CRM value of $683 \mathrm{~kg}, 12 \%$ and 6.2 respectively, showed the tendency of the model to under predict the grain yield by $6.2 \%$. With respect to simulation here it was considered as good as the NRMSE values was $12 \%$. The lower value for RMSE reflected that the model predicted grain yield quite well (Figure 3).

\section{Nitrogen uptake by grain}

Observed values of nitrogen uptake was closer to the simulated values with RMSE of $13 \mathrm{~kg} \mathrm{ha}^{-1}$. The positive CRM value of 11.4 showed the tendency of model to under predict the nitrogen uptake by $11.4 \%$. However, the simulation was considered as good with NRMSE value of $16 \%$ (Figure 4).

In conclusion, CERES-Rice model can be used as a tool to identify suitable management strategies to improve the rice yield under transplanted conditions as the simulation of phenology was considered as excellent and for biomass and grain yield the simulation was considered as good.

\section{References}

Ducheyne, S. 2000. Derivation of the parameters of the WAVE model using a deterministic and a stochastic approach. Ph.D Thesis No. 434, Faculty of Agriculture and Applied Biological Sciences, K.U. Leuven, Belgium. 123.

Hoogenboom, G., Jones, J.W., Porter, C.H., Wilkens, P.W., Boote, K.J., Batchelor, W.D., Hunt, L.A., Tsuji, G.Y. 2003. Decision Support System for Agrotechnology Transfer version 4.0. Volume 1: Overview. University of Hawaii, Honolulu, HI. 2.

Hoogenboom, G., Jones, J.W., Wilkens, P.W., Porter, C.H., Boote, K.J.,
Hunt, L.A., Singh, U., Lizaso, J.L., White, J.W., Uryasev, O., Royce, F.S., Ogoshi, R., Gijsman, A.J., Tsuji, G.Y. 2010. Decision Support System for Agrotechnology Transfer version 4.5 [CD-ROM]. University of Hawaii, Honolulu, Hawaii.

IRRI. (International Rice Research Institute) 1997. Annual report 1996-97. Rice research : the way forward. Los Banos. Int. Rice Res. Institute, Philippines.

Loague, K., Green, R.E. 1991. Statistical and graphical methods for evaluating solute transport models: Overview and application. J. Contaminant Hydrol., 7: 51-73.

Rice Knowledge Management Portal (RKMP). 2013. Directorate of Rice Research, Rajendranagar, Hyderabad. http://www.rkmp.co.in

Rinaldi, M., Ventrella, D., Gagliano, C. 2007. Comparison of nitrogen and irrigation strategies in tomato using CROPGRO model. Agri. Water Management, 87(1): 91-105.

Ritchie, J.T., Alocijia, E.C., Uehara, G. 1986. IBSNAT/CERES-Rice Model. Agrotechnol. Transfer, 3: 1-5.

Sarwa, N., Maqsood, M., Wajid, S.A., Haq, M.A. 2011. Impact of nursery seeding density, nitrogen, and seedling age on yield and yield attributes of fine rice. Chilean $J$. Agri. Res., 71(3): 343-349.

Swarna, R. 2013. Evaluation of CERES-rice model under variable nitrogen levels and plant densities. M.Sc(Ag) Thesis submitted to ANGR Agricultural University, Hyderabad.

Thornton, P.K., Hoogenboom, G. 1994. A computer program to analyze singleseason crop model outputs. Agronomy J., 86: 860-868.

Thornton, P.K., Hoogenboom, G., Wilkens, P.W., Bowen, W.T. 1995. A 
computer program to analyze multiple-season crop model outputs. Agronomy J., 87: 131-136.

Wallach, D., Goffinet, B. 1989. Mean squared error of prediction as a criterion for evaluating and comparing system models. Ecol. Modelling, 44: 200-306.

Xevi, E., Gilley, J., Feyen, J. 1996. Comparative study of two crop yield simulation models. Agri. Water Management, 30: 155-173.

\section{How to cite this article:}

Vijayalaxmi, G., G. Sreenivas and Leela Rani, P. 2016. Evaluation of CERES-Rice Model under Various Plant Densities and Age of Seedlings in Transplanted Rice in Southern Telangana Zone of Telangana State, India Int.J.Curr.Microbiol.App.Sci.5(4): 667-674. doi: http://dx.doi.org/10.20546/ijcmas.2016.504.076 